\title{
Cryopreservation of Iranian Markhoz goat fibroblast cells as an endangered national genetic resource
}

\author{
Zahra Elyasi Gorji ${ }^{1}$ Parvaneh Farzaneh ${ }^{1}$ - Ahmad Nasimian ${ }^{1} \cdot$ Meysam Ganjibakhsh ${ }^{1} \cdot$ Mehrnaz Izadpanah $^{1}$. \\ Maryam Farghadan ${ }^{1} \cdot$ Faezeh Vakhshiteh $^{1}$. Hedieh Rahmati ${ }^{1}$. Seyed Abolhassan Shahzadeh Fazeli ${ }^{1,2}$. \\ Hamidreza Khaledi ${ }^{1,3} \cdot$ Abdolreza Daneshvar Amoli $^{1}$
}

Received: 20 January 2021 / Accepted: 29 June 2021 / Published online: 16 August 2021

(c) Springer Nature B.V. 2021

\begin{abstract}
Background The continuous accessibility of local animals for sustainable use is being eroded annually. Thus, a strategic vision for the conservation of biodiversity is of far-reaching emphasis to deal with unprecedented challenges in the local population extension facing in the future. This study aimed to establish and cryopreserve endangered Markhoz goat (Capra hircus) fibroblast cell lines in vitro.

Methods and results These primary fibroblast cells were isolated from 58 Iranian Markhoz goats and individually cultured by explant technique in DMEM medium supplemented with 10\% FBS and $2 \mathrm{mM}$ L-Glutamine, in the presence of Penicillin $(200 \mathrm{U} / \mathrm{ml})$ - Streptomycin $(200 \mathrm{mg} / \mathrm{ml})$ during the first passage number. The extracted cell lines were confirmed morphologically as fibroblast cells. The population doubling time for DMEM-cultured cells was $23 \pm 0.5 \mathrm{~h}$. Chromosomal analysis indicated a total chromosome number of $2 n=60$ with $>95 \%$ frequency. The cultured cells were checked for bacteria, fungi, yeast, and mycoplasma contaminations and the results were reported negative. The efficiencies of the fluorescent protein encoded by VSV-G (pMDG) and lentiviral pCSGW vectors reported in a range of $65 \%$ value. According to the species identification analysis, the goat cell lines were banked and confirmed without any miss- and cross-contamination.

Conclusions The significant issue in this paper can be concluded about the first report of the establishment of endangered Markhoz goat cell banking inside the country. This study demonstrated the successful establishment of a genetically stable fibroblast bank as a valuable genetic resource for the endangered Iranian Markhoz goat breed.
\end{abstract}

Keywords Markhoz cell line $\cdot$ Explant technique $\cdot$ Primary cell preservation $\cdot$ Molecular characterization

Hamidreza Khaledi and Abdolreza Daneshvar Amoli have contibuted equally to this work.

Hamidreza Khaledi

k_khaledi2000@yahoo.com

$\triangle$ Abdolreza Daneshvar Amoli

daneshvaramoli@gmail.com; daneshvar@ibrc.ir

1 Human and Animal Cell Bank, Iranian Biological Resource Center (IBRC), ACECR, 1551916111 Tehran, Iran

2 Department of Molecular and Cellular Biology, Faculty of Basic Sciences and Advanced Technologies in Biology, University of Science and Culture, Tehran, Iran

3 Department of Agriculture, Yadegar-e-Imam Khomeini (rah), Shahr-e- rey Branch, Islamic Azad University, Tehran, Iran

\section{Introduction}

Biodiversity conservation aims to manage the human use of natural resources to get the sustainable benefit of present and future generations. Preservation of genetic resources implies the different aspects of economic, social, and cultural issues, which lead to the establishment of productive ecosystems to develop a sustainable community [1]. The loss of the livestock species inside certain geographic areas causes the abolishment of the variability of the animal genetic resources and extinction [2]. Therefore, the conservation of genetic resources from native breeds, wild types, and domestic animals is the key factor to protect biodiversity in a distinct ecosystem [3-5].

There are various complementary strategies for the conservation of animal resources which including in vitro and in vivo. In vitro techniques include the cryopreservation of 
sperm/ovule, embryos, genomic libraries, and somatic cell lines [6]. One of the significant in vitro approaches in cryopreservation technology is the establishment of the fibroblast cell lines $[3,7,8]$. Fibroblast cells represent a rapid growth feature and early genetic screening that makes it a favorable cell type of conservation [9]. Several reports indicated the establishment of the fibroblast cell lines from various animals which including the Caspian horse [10], Sistani cattle [11], Fars native goat fetal [12], Simmental cattle [13], Texel sheep [3], and Luxi cattle [14]. These studies operated one of these two techniques to cultivate tissue, including enzymatic and direct explant techniques [15].

Markhoz goats, a class of small domestic ruminants, can tolerate unpleasant conditions to survive. The favorable habitat for this breed is the Kurdistan province of Iran, known as the center of mohair by-products obtained from this breed. Mohair plays the basic cultural role in making local clothes in Kurdistan [16]. It is also noteworthy that this breed is a valuable source of red meat $(102,000$ tons per year) in arid and semi-arid areas of Iran [17]. So it can be characterized as a multipurpose animal [18].

An uncomfortable observation indicated that the population size of the Markhoz goat is decreasing annually. In comparison to the last decades, the distribution of this breed is limited in a few villages of Western Azerbaijan and a small part of Kurdistan. Based on the data obtained by Agricultural Jahad of Kurdistan (AJOK), there is a downward slope of Markhoz goat population size (22,000 to 5000) from 1996 to 2005 [19], with a further decrease during the recent years [18]. Therefore, the Markhoz goat is an endangered animal threatened for extinction [20]. According to the strategic role of Markhoz goat in making the waterproof fabrics by Mohair in textile industries, biodiversity conservation of this breed is crucial. Furthermore, due to its impressive adaptability to the environment $[18,20]$, the establishment of fibroblast cell bank, as an unlimited source of genetic pool, leads to further studies for genetic improvement and variability to enhance its future productive performances. This work can employ future exhaustive studies, including characterization of molecular markers for the management strategies and improvement of specific traits in endangered populations [18].

The essential aim of this research was the conservation of fibroblast cell lines derived from the ear margin tissues of Markhoz goat (named CpHi). The derived cell lines were cultured by explant technique and the established cell lines were cryopreserved followed by assessment of the cell viability, microbial quality control, chromosome analysis, species identification, and genes transfection of fluorescent proteins. Fibroblast cell cryopreservation is a fast and valuable strategy to develop a convenient and advantageous genetic pool for future genomic studies and the possible revival of this animal by genetic engineering [13]. Furthermore, the progression of novel technologies and introducing new achievements in future researches will increase the probability of utilization of these established cell lines in different branches, including tissue engineering, reprogramming, and producing extracellular matrix using these somatic cells [21].

\section{Materials and methods}

\section{Primary fibroblast cell isolation and culture}

In the present study, the ear samples from 58 specimens of Markhoz goat were obtained from the Ministry of Jahad Agriculture, Research Center, Sanandaj, Kurdistan province, Iran. The ethical approval of sampling protocols arranged and confirmed by the human and animal cell bank of IBRC.

The small pieces of animal ear samples were moved to the laboratory using PBS containing Penicillin (200 U/ml) Streptomycin $(200 \mathrm{mg} / \mathrm{ml})$. The fibroblast cells were isolated from the received sample using the explant technique described by Gorji et al. (2017) [11]. In brief, each sample was dissected out into small pieces of $1 \mathrm{~mm}^{3}$ in size, placed on the surface of the culture plate ( $32 \mathrm{~mm}$ diameter), fixed by pre-cleaned $18 \times 18 \mathrm{~mm}$ coverslip glass, and cultured in Dulbecco's Modified Eagle's Medium (DMEM) containing $10 \%$ fetal bovine serum (FBS), $2 \mathrm{mM}$ L-Glutamine and Penicillin $(200 \mathrm{U} / \mathrm{ml})$-Streptomycin $(200 \mathrm{mg} / \mathrm{ml})$. After that, the culture plates were kept and incubated at $37{ }^{\circ} \mathrm{C}$ with $5 \%$ $\mathrm{CO}_{2}$ and $95 \%$ humidity during one week. In this period, the cell culture was checked routinely to investigate the probable contaminations and to refresh the culture medium.

\section{Cell proliferation and cryopreservation}

The cells were proliferated and cryopreserved according to Stacey et al. (2008) protocol, but with a few modifications [22]. After a week, the non-contaminated cultured cells reached $70-80 \%$ confluency and were detached from the culture plate using $0.025 \%$ trypsin- $0.02 \%$ EDTA solution and sub-cultured into $25 \mathrm{~mm}^{2}$ cells culture flasks. In continue, the cells were cultured using the free-antibiotic DMEM medium containing 10\% FBS, and $2 \mathrm{mM} \mathrm{L-Glu-}$ tamine followed by kept at $37{ }^{\circ} \mathrm{C}$ with 5\% $\mathrm{CO} 2$ and $95 \%$ humidity. The medium was changed every two or three days, and the cells were checked routinely for their density and morphology. Finally, the cells were cultured into $75 \mathrm{~mm}^{2}$ cell culture plates, harvested, and counted using a trypan blue solution. Around $1 \times 10^{6} \mathrm{cells} / \mathrm{ml}$ was resuspended in a freezing medium containing $90 \%$ FBS and $10 \%$ dimethyl sulfoxide (DMSO). The cell suspension was stored in sterile plastic cryovials labeled with the species name, cell ID number, cell count, and the date of freezing. The cryovials were then kept at $4{ }^{\circ} \mathrm{C}$ for $60 \mathrm{~min},-80{ }^{\circ} \mathrm{C}$ overnight, and 
$-196^{\circ} \mathrm{C}$ nitrogen vapor phase for long-term storage. For cell reseeding, the cryovials were taken out from the nitrogen vapor phase after two weeks, six months, and one year of storage. The cell viability before freezing and after thawing was measured by the trypan blue staining method. For the growth rate estimation, the three registered cell lines were seeded into 24 -well plates at a density of $5 \times 10^{4}$ cells $/ \mathrm{ml}$ and cultured for 6 days in three repeats. After that, the cells were counted every day triplicate, and the mean cell numbers at each day were plotted versus time, followed by the determination of the population doubling time (PDT).

\section{Chromosome analysis}

The chromosome analysis was investigated by the protocol configured by Gorji et al. (2017) but with some modifications [11]. In brief, the cells were prepared in 50-60\% confluency, and then colchicine was added into the medium at the concentration of $20 \mu \mathrm{g} / \mathrm{ml}$. The medium was then removed after $1 \mathrm{~h}$ and washed with PBS. After that, the cells were trypsinized, centrifuged at $300 \times g$ for $5 \mathrm{~min}$, and then the supernatant was removed. The hypotonic solution, $0.075 \mathrm{M}$ $\mathrm{KCl}$, was mixed gently with cell pellet and then incubated for $1 \mathrm{~h}$ at $37^{\circ} \mathrm{C}$. After hypotonic treatment, $1 \mathrm{ml}$ of cold fixative (3:1 methanol and acetic acid) was added and centrifuged for $10 \mathrm{~min}$ at $300 \times \mathrm{g}$. Finally, this step was repeated by the addition of a $5 \mathrm{ml}$ cold fixative solution. The remained suspension was dried on glassy slides at $60{ }^{\circ} \mathrm{C}$ for $18 \mathrm{~h}$. For Giemsa staining, the slides were placed in a trypsin solution $(0.025 \%)$ for $35 \mathrm{~s}$, and then the slides were exposed to PBS solution followed by stained with Giemsa for $7 \mathrm{~min}$. Finally, the slides were then investigated for at least 10-20 metaphases.

\section{Microorganism detection}

In order to recognition of mycoplasma contamination, fluorescent DNA staining was investigated according to the protocol defined by Guan et al. (2005) [23]. For this reason, the cells were cultured in an antibiotic-free medium and stained with Hoechst 33,258 (Sigma, USA). To confirm the results of nucleus staining, the PCR method was also performed using the protocol released by Uphoff et al. (2002) [24]. The primers used in PCR method could detect the most common mycoplasma species, including Mycoplasma orale, Mycoplasma hyorhinis, Mycoplasma arginini, Mycoplasma fermentans, Mycoplasma hominis, Mycoplasma bovis, and Acholeplasma laidlawii [24]. For microbial contaminations, the culture plates were investigated microscopically for the presence of fungi, yeast, and bacterial contaminations every day, and the cell supernatant (antibiotic-free) was cultured in microbial culture medium containing Thioglycollate Broth and Tryptone Soy Broth medium for 14 days in $22{ }^{\circ} \mathrm{C}$ and $32{ }^{\circ} \mathrm{C}$ separately.

\section{Species identification}

Genomic DNA was extracted from primary cells via a column-based DNA extraction kit (IBRC, Iran). The authentication of the primary cells was confirmed by the multiplex PCR method assembled using the amplification of cytochrome $\mathrm{C}$ oxidase subunit I (COI) mitochondrial gene. The specific primers were used according to the study reported by Cooper et al. (2007) [25]. Different animal species include mouse, rat, rabbit, camel, horse, cow, sheep, cat, dog, guinea pigs, pig, rhesus monkey, African green monkey, Chinese hamster, human, chicken, and goat could be detected by this method.

\section{Transfection of fluorescent proteins}

According to the lentivirus production, 293LTV cells were seeded onto a culture plate and then transfected with $13.5 \mu \mathrm{g}$ of transfer vector pCSGW, which carries PTP1B shRNA or cDNA, $9 \mu \mathrm{g}$ of pCMVDR8.91, and $4.5 \mu \mathrm{g}$ of pMDG using poly ethylenimine. Subsequently, the viruses were harvested after $48 \mathrm{~h}$ by passing through a $0.45 \mu \mathrm{m}$ pore-sized filter and concentrated by ultracentrifugation at $100,000 \times g$ for $90 \mathrm{~min}$. Finally, to complete the infection, the Markhoz cells were transduced at multiplicities of infection (MOI) 6 for $16 \mathrm{~h}$. After that, the infected medium was removed and the cells were cultured in the absence of a virus for the next $72 \mathrm{~h}$. The relative fluorescence intensity of the induced fluorescent proteins was evaluated and recorded by a fluorescent microscope. The HIV packaging (pCMVDR8.91), VSV-G (pMDG) plasmids, and the lentiviral pCSGW vector have been purchased from the Stem Cell Technology Center (Bonyakhteh).

\section{Results}

\section{Establishment of Markhoz goat fibroblast cell line}

It was observed that Markhoz cells emerged from tissue pieces into the culture flask around two to three days after being explanted. In the first days, the migrated cells included a combination of fibroblast-like cells and also epithelial-like cells, however, because of using fibroblast culture mediums, a relative pure fibroblast line was observed after passages number three (Fig. 1a). The cells were cryopreserved in freezing media (90\% FBS and $10 \%$ DMSO) at passage number three, in a density of $1 \times 10^{6}$ number/ml. The average viability before freezing and after thawing was estimated at $95-99 \%$ and $90-95 \%$ respectively. Furthermore, the cells could grow in several passage numbers after defreezing (Fig. 1b), which represented the optimal cell culture condition and cryopreservation process. 

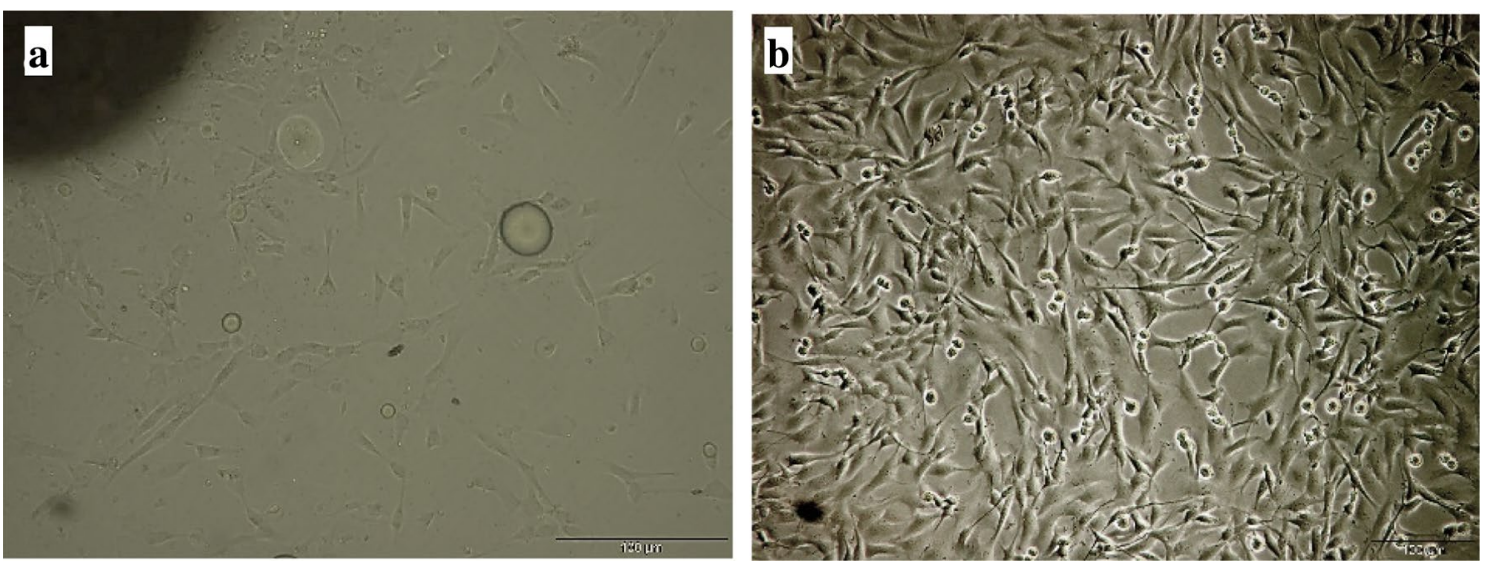

Fig. 1 Growth of the goat fibroblast cells after the in vitro explant culture (a), $48 \mathrm{~h}$ after recovery (b)

\section{Growth curve of Markhoz cells}

As shown in Fig. 2, the cell growth curves were plotted in the style of "s" shape and the population doubling time was calculated approximately $23 \pm 0.5 \mathrm{~h}$. As shown in this diagram, the lag phase lasted about two days, followed by three days exponential phase. Finally, the stationary phase was reached after about four days and took along for two days.

\section{Microbial analysis of primary cultured cells}

Based on the comprehensive investigations in microorganisms detections, the visible analysis by the naked eye, PCR analysis for mycoplasma (Fig. 3a), microbial culture assay, and Hoechst DNA staining (Fig. 3b, c) represented that the Markhoz goat cell culture medium did not display any contaminations by mycoplasma, bacteria, yeast, and fungi.

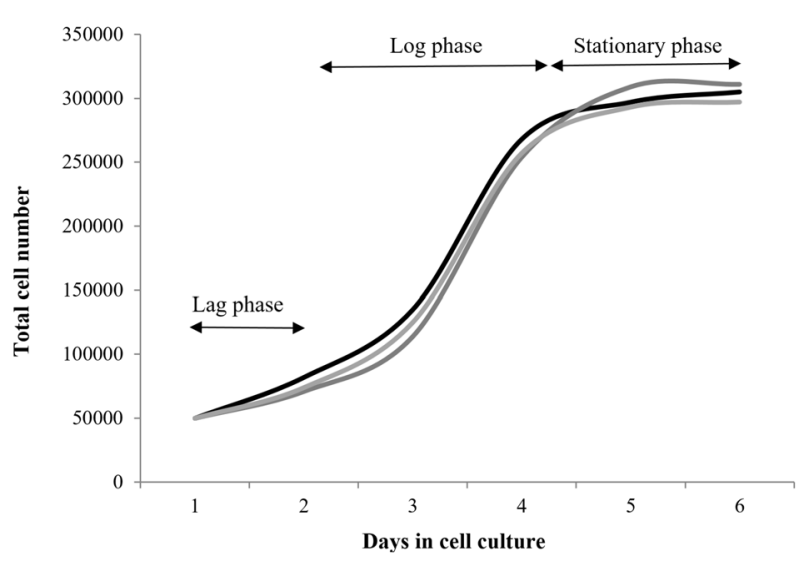

Fig. 2 Growth curve of the goat fibroblasts. The curve has a typical "S" shape including lag phase, log growth phase, and stationary phase

\section{Species identification of Markhoz cell collection}

As shown in Fig. 4, the PCR analysis for species identification confirmed the pure originality of Markhoz goat cell lines and did not represent any cross-contamination according to this method.

\section{Chromosome analysis of Markhoz cells}

Karyotyping analysis revealed that the chromosome number of the Markhoz goat was $2 n=60$ with $>95 \%$ frequency in distribution which carrying the 29 pairs of autosomal chromosome showing the acrocentric pattern and one pair of sex chromosomes showing the sub-metacentric pattern. In this experiment, 50 independent spreads of metaphase step were observed under the microscope using by the cells at passage numbers 3-5, and the chromosome distribution patterns (Fig. 5a) and numbers (Fig. 5b) was figure out.

\section{Transfection of fluorescent proteins}

According to the pictures obtained by the fluorescence inverted microscope (Fig. 6) the virus, which was carrying fluorescent protein genes, could be transfected successfully into the Markhoz cells with around 60-65\% efficiency rate after $72 \mathrm{~h}$ of infection.

\section{Discussion}

The contemporary biodiversity conservation problem is determined by the reduction and extinction of various animal populations and species all over the world [26]. Policy-makers in many countries are seldom aware of the diverse and significant contributions of animal genetic resources of food and agriculture. High-yielding domestic animals are one of the 


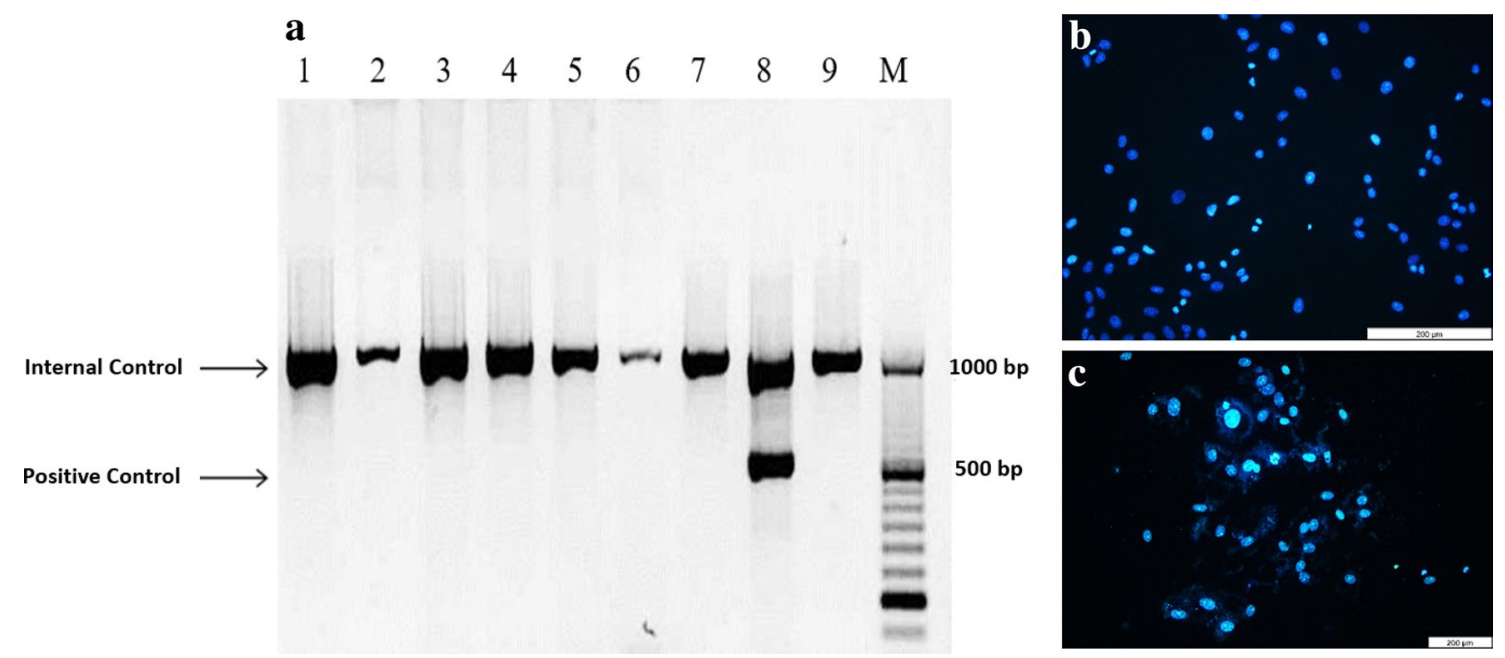

Fig. 3 Gel electrophoresis of multiplex PCR for mycoplasma detection using specific primers (a) and analysis of microbial quality control in Markhoz goat primary cell cultures (b-c). Lanes 1-7a demonstrated the $\mathrm{CpHi}$ cell lines without any mycoplasma contamination. Lane 8a showed mycoplasma positive control and lane 9a represented mycoplasma negative control. Identification of $1000 \mathrm{bp}$ band was considered as multiplex PCR internal control. DNA staining with Hoechst 33,258 represented a clean cell culture condition without any microbial contamination (b) and positive control (c)

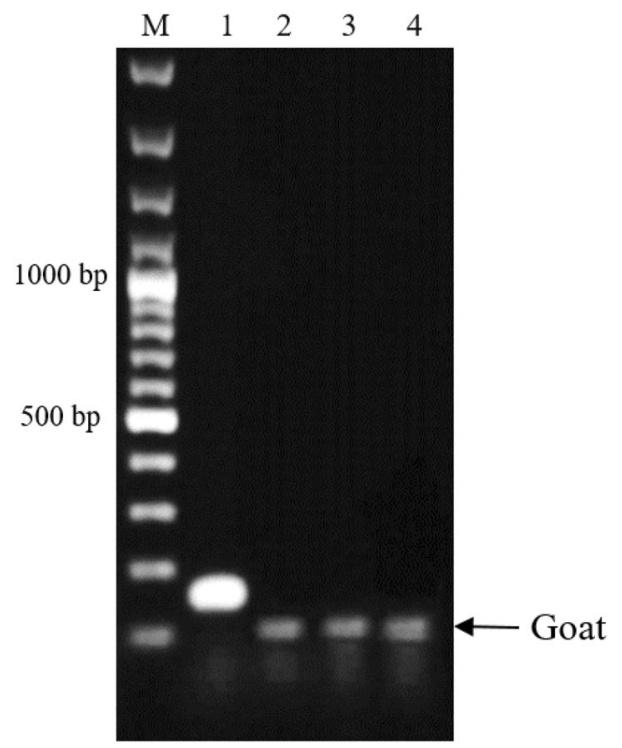

Fig. 4 Gel electrophoresis of multiplex PCR for species identification with specific primers. Lanes 2-4 represented 117 bp specific band for the Markhoz goat with no cross-contamination. Lane 1 was used as a control group, which showed a cell line with the origin of the mouse

biodiversity challenges throughout the world, which can raise damage risk of the local animals. Native animals are a valuable resource of genetic pools for their potential resistance and adaptation to adverse biological conditions. Therefore, a strategic vision for conservation and sustainable use of biodiversity is the sustainable development of the economy and society [4].
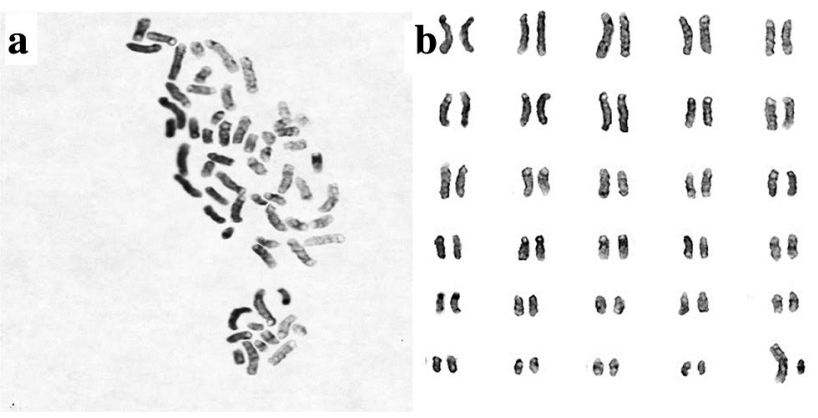

Fig. 5 Metaphase spread (a) and karyotype analysis (b) of the Markhoz goat fibroblast cells. The chromosomes number was calculated $2 n=60$. The $X$ chromosome was identified as the longest chromosome and the $\mathrm{Y}$ chromosome was categorized as the shortest chromosome in this species

Reduction of animal specified native area, population size and herd numbers are the main indicators of obligatory danger of native animal extinction in the close future [27]. Native genes of endangered breeds should be conserved as much as possible for the increasing of the chance of somatic cell cloning to reproduce these breeds after extinction. Therefore, the conservation of endangered animals has become an urgent issue $[28,29]$. The ideal priority to conserve the animal breeds is the live population preservation; however, this approach is expensive and unless the breed can be used for production, it is not almost to be economic. Therefore, the in vitro conservation strategies emerged to cryopreserve animal genetic resources according to the genome/gene banks with the hope to manage 


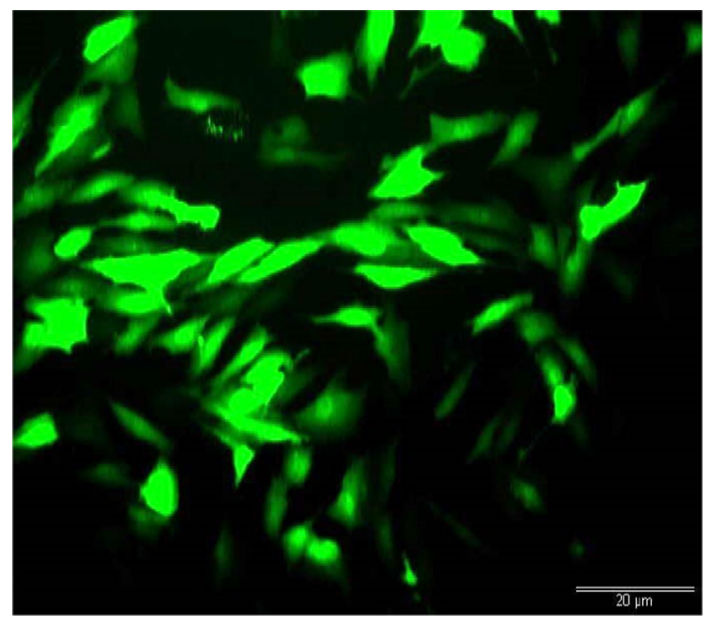

Fig. 6 Expression rate of the GFP in Markhoz goat fibroblast after $72 \mathrm{~h}$ gene transduction. The gene expression was recorded using a fluorescent microscope

the exchange of genetic diversity or regenerate a particular population in the future $[30,31]$. The main in vitro conservation approaches of livestock genetic resources have been focused on cryopreservation of gametes, embryos, and somatic cells as well as testis and ovarian tissues [31, 32]. However, according to the comprehensive studies, the above-mentioned conservation programs lack of a standardized protocol to apply for any kind of embryos [33], oocytes [34], and sperms [34] which seems to be a difficult procedure.

Fibroblast cells, considered as a source of disease modeling after cell reprogramming, are characterized as a group of cell culture with easily accessible in the body as a transient primary cell culture or permanent transformed cell line [35]. The fibroblast-like cell culture from the Markhoz native goat was established using the explant culture method followed by storing the cells at passage number three. In this experiment, the primary explant culture technique was applied in small pieces of tissue with rather lower risks of losing cells than other methods [3]. The analysis of this study indicated that established Markhoz goat fibroblast primary cells grew rapidly, which was genetically stable with correct species identification, and not any cross-contamination. Morphological observation showed both epithelial and fibroblast cells during the first passages of the explanted tissues. Since most epithelial cells were difficult to adhere to and solely attach in an unstable manner, a purified fibroblast line could be obtained after three passages $[23,36]$. To protect the potential biological and genetic alternation in vitro culture, cells were cryopreserved in a minimal number of passages [37]. The survival rate after freezing decreased to some extent, possibly due to the cell injury that occurred during the process of freezing and recovery. However Stacey et al. (2008) believed for most of cell types at least $80 \%$ cell viability can be accepted [22]. The isolated cells were then examined for bacteria, yeast, fungi and mycoplasma contamination. Since the removal of the mycoplasma is difficult due to the coexistence of the cells for a long period, the contaminated cells with mycoplasma removed from the cell culture process exactly after the detection [3]. The best methods for mycoplasma detection includes direct solid agar microbial culture, indirect DNA fluorescent staining, and PCR method [38]. In this study, a combination of the abovementioned methods was performed as the best overall testing approaches. The free of mycoplasma goat fibroblasts were preserved according to the experimental tests determined by Hoechst 33,258 staining followed by confirmation of PCR methods.

Similar to the previous research the karyotype analysis represented the $2 n=60$ chromosomes, with the sex chromosomes $\mathrm{X}$ and $\mathrm{Y}$ [39]. The diploid frequency of chromosome distribution was $70-75 \%$, hence, it can be claimed that the Markhoz goat fibroblast cell culture was stably diploid. In this research, the expression of fluorescent proteins was around $65 \%$, which different factors including plasmid DNA concentration and incubation time, lipofectamine concentration and combination, and the utilization of serum in the medium can influence cell transfection efficiency [40, 41]. However, the important issue was that under the standard conditions, the transfected cells had not shown any different growth rate, cell shape, and cell proliferation in comparison to untransfected cells. The Markhoz fibroblast exogenous gene expression can be important in the future for the identification of specific genetic markers of this breed, and transgenic cloning research. Furthermore, in comparison to specialized cell lines, such as B-cells, foreign genes can be transfected and expressed in fibroblast cells in very facile conditions because fibroblast cell lines are less differentiated [42].

\section{Conclusions}

This study demonstrated the establishment of the genetically stable Markhoz goat fibroblast cell lines which are classified as the endangered extinction breed, followed by meet the criteria of the quality standards of the international cell banking collections. The established cell lines can be proposed as valuable experimental materials for genomics, postgenomics, cloning, and molecular fields of future studies.

Acknowledgements This study was completed in the Iranian Biological Resources Center. The authors express their gratitude to the Dr. Farzaneh who lost her life due to Covid-19 pandemic. Her kind personality, ethic and scientific enthusiasm will stay in our memory forever. 


\section{Declarations}

Conflict of interest The authors declare no conflict of interest in the present study, and no significant financial support for this work could have influenced its outcome.

Ethical approval This work was not submitted to any other journal in any form, and the results of this study were not used in any animal experiments or human studies.

Consent for participation This manuscript has been read and approved by all named authors and that are no other persons who satisfied the criteria for authorship but are not listed. All the authors of this publication have a draft copy of this paper and are agree to participate in this manuscript with the proposed structure.

Consent for publication The authors of this manuscript declare their consent to publish the results of study in this journal.

\section{References}

1. Niesenbaum RA (2019) The integration of conservation, biodiversity, and sustainability. Multidisciplinary Digital Publishing Institute, Basel

2. Rege JEO, Gibson JP (2003) Animal genetic resources and economic development: issues in relation to economic valuation. Ecol Econ 45(3):319-330

3. Li LF et al (2009) Establishment and characterization of a fibroblast cell line derived from Texel sheep. Biochem Cell Biol 87(3):485-492

4. Li L-F et al (2009) Establishment and characterization of a fibroblast cell line from the Mongolian horse. Vitro Cell Dev BiolAnimal 45(7):311-316

5. Mehrabani D et al (2014) Establishment, culture, and characterization of Guinea pig fetal fibroblast cell. Vet Med Int. https://doi. org/10.1155/2014/510328

6. Prentice JR, Anzar M (2011) Cryopreservation of mammalian oocyte for conservation of animal genetics. Vet Med Int 2011:1-11

7. JM LIU et al (2007) Establishment and cryopreservation of red panda fibroblast cell line [J]. J Anhui Agric Univ 2007:1

8. Guan W et al (2010) Establishment and cryopreservation of a fibroblast cell line derived from Bengal tiger (Panthera tigris tigris). CryoLetters 31(2):130-138

9. Zhang Q et al (1998) Isolation, culture and characterization of a primary fibroblast cell line from channel catfish. Cytotechnology 26(2):83-90

10. Amoli AD et al (2017) Establishment and characterization of Caspian horse fibroblast cell bank in Iran. Vitro Cell Dev Biol-Animal 53(4):337-343

11. Gorji ZE et al (2017) Establishment and characteristics of Iranian Sistani cattle fibroblast bank: a way to genetic conservation. Conserv Genet Resour 9(2):305-312

12. Mehrabani D et al (2016) Establishment, characterization and cryopreservation of Fars native goat fetal fibroblast cell lines. Asian Pac J Reprod 5(3):247-251

13. Ibrahim AG et al (2009) Restoration of hand function in a rat model of repair of brachial plexus injury. Brain 132(5):1268-1276

14. Liu C et al (2008) Establishment and biological characteristics of Luxi cattle fibroblast bank. Tissue Cell 40(6):417-424
15. Klingbeil MFG et al (2009) Comparison of two cellular harvesting methods for primary human oral culture of keratinocytes. Cell Tissue Bank 10(3):197-204

16. Farshad A et al (2008) The estrous cycle of the Markhoz goat in Iran. Asian Australas J Animal Sci 21(10):1411-1415

17. Goodarzi N, Hosseini T (2013) Morphometric characteristics of the maxillofacial and mandibular regions of Markhoz goat breed and its clinical value for regional anaesthesia in western Iran. Global Vet 11(1):107-111

18. Asroush F et al (2018) Genetic characterization of Markhoz goat breed using microsatellite markers. Arch Animal Breed 61(4):469-473

19. Bahmani HR et al (2011) Assessment of demographic, geographical and genetic risks in Markhoz goat population. J Animal Vet Adv 10:162-168

20. Pourali $S$ et al (2020) Investigating the polymorphism of bone morphogenetic protein receptor-1B (BMPR1B) gene in Markhoz goat breed. Animals 10(9):1582

21. Franco-Barraza J et al (2016) Preparation of extracellular matrices produced by cultured and primary fibroblasts. Curr Protoc Cell Biol. https://doi.org/10.1002/cpcb.2

22. Stacey GN, Masters JR (2008) Cryopreservation and banking of mammalian cell lines. Nat Protoc 3(12):1981

23. Guan W et al (2005) The establishment of fibroblast cell line and its biological characteristic research in Taihang black goat. Rev China Agric Sci Technol 7:25-33

24. Uphoff CC, Drexler HG (2002) Comparative PCR analysis for detection of mycoplasma infections in continuous cell lines. In Vitro Cell Dev Biol-Animal 38(2):79-85

25. Cooper JK et al (2007) Species identification in cell culture: a two-pronged molecular approach. In Vitro Cell Dev Biol-Animal 43(10):344-351

26. Cooke SJ (2008) Biotelemetry and biologging in endangered species research and animal conservation: relevance to regional, national, and IUCN Red List threat assessments. Endang Species Res 4(1-2):165-185

27. Bahmani HR et al (2011) Assessment of demographic, geographical and genetic risks in Markhoz goat population. J Animal Vet Adv 10(2):162-168

28. Li X et al (2009) Establishment and characterization of a fibroblast cell line derived from Jining Black Grey goat for genetic conservation. Small Rumin Res 87(1-3):17-26

29. Dohner JV (2001) The encyclopedia of historic and endangered livestock and poultry breeds. Yale University Press, New Heaven

30. Hanks J (2001) Conservation strategies for Africa's large mammals. Reprod Fertil Dev 13(8):459-468

31. Holt WV, Pickard AR (1999) Role of reproductive technologies and genetic resource banks in animal conservation. Rev Reprod $4: 143-150$

32. Andrabi S, Maxwell W (2007) A review on reproductive biotechnologies for conservation of endangered mammalian species. Animal Reprod Sci 99(3-4):223-243

33. Fair $\mathrm{T}$ et al (2001) Ultrastructure of bovine blastocysts following cryopreservation: effect of method of blastocyst production. Mol Reprod Dev 58(2):186-195

34. Woods EJ et al (2004) Fundamental cryobiology of reproductive cells and tissues. Cryobiology 48(2):146-156

35. Fernandes I et al (2016) Fibroblast sources: where can we get them? Cytotechnology 68(2):223-228

36. Zhou $X$ et al (2005) Establishment and characteristics of a Beijing fatty chicken embryo fibroblast cell line. Acta Vet et Zootech Sin 36(3):209-215

37. Hasoon MF et al (2013) Development and biological characteristics of brown quail (Coturnix ypsilophora) embryonic fibroblast primary cells. JWPR 3:68-72 
38. Ryan J (2009) Understanding and managing cell culture contamination. Corning Technical Bulletin, Corning

39. Iannuzzi L, Di Meo GP, Perucatti A (1996) G-and R-banded prometaphase karyotypes in goat (Capra hircus L.). Caryologia 49:267-277

40. Escriou $\mathrm{V}$ et al (2001) Critical assessment of the nuclear import of plasmid during cationic lipid-mediated gene transfer. J Gene Med 3(2):179-187

41. Rui R et al (2006) Establishment of porcine transgenic embryonic germ cell lines expressing enhanced green fluorescent protein. Theriogenology 65(4):713-720
42. Bouchard B et al (1989) Induction of pigmentation in mouse fibroblasts by expression of human tyrosinase cDNA. J Exp Med 169(6):2029-2042

Publisher's Note Springer Nature remains neutral with regard to jurisdictional claims in published maps and institutional affiliations. 